\title{
UIT DE ECONOMIST VAN 1869
}

Voorzeker heeft onze volkaard vele gewoonten die wij bij een verblijf in den vreemde slechts te meer leeren waardeeren, doch, men ontkenne het niet, er is ook wel een en ander dat wij van onze naburen met voordeel konden overnemen. Bepalen wij ons tot een paar zeer alledaagsche zaken.

Ik neem b.v. den leefregel en sommige inrigtingen onzer huishouding, - in de eerste plaats, de voeding. Zonder overdrijving mogen wij zeggen dat Duitschers, Franschen en Engelschen dienaangaande een beteren regel volgen dan wij. Hoe is b.v. doorgaans regel in het meerendeel - welligt 90 van de 100 - der Hollandsche huishoudens? Men ontbijt circa acht ure of half negen, met thee en boterhammen, opgeluisterd met roggenbrood of kaas, misschien rookvleesch of nu en dan een eitje, en op dat schrale diëet gaat men den dag te gemoet en den gewonen arbeid beginnen, welke die ook zij. Ten half een ure is er repetitie van 't voorgaande, doch koffij in plaats van thee, koek in plaats van kaas; - andermaal gaat men aan zijne werkzaamheden, bureau, of wandeling, societeit enz., en dan, te 5 ure eten. Het middagmaal op zich zelf is bij ons zeker goed, dikwijls beter dan in het buitenland: - heerlijke runderribben, zwaar kalfsvleesch, keurige groenten, waar vindt men ze als in Holland! - tegen het Hollandsche diner op zich zelf valt dus uit een gezondheids oogpunt eigenlijk niets aan te merken, (welligt dat krachtige soep wat zeldzaam in het menu voorkomt, bij een veelvuldig optreden van grutterswaren), - doch in verband met onze overige maaltijden heeft het Hollandsch etensuur dit nadeel, dat het, zelfs te 5 ure, eigenlijk nog te vroeg of te laat is: te vroeg, wanneer men dientengevolge nog eens soupeert, soms vrij stevig, ten 10 of $10 \frac{1}{2}$ ure; te laat, wanneer aan het middagmaal (zooals bij een overgroot gedeelte zelfs der zeer gegoede ingezetenen) het eerste vleeschvoedsel van den geheelen dag wordt genuttigd. Dat schijnt ons toch eene verkeerde gewoonte: goed gebraden vleesch verteert gemakkelijk, en geeft, 's morgens genuttigd, verder op den dag gedurende den lichaamsof geestesarbeid, een gevoel van kracht en opgewektheid.

De Hollandsche leefwijze. Een blik over de grenzen. (blz. 741-742) 